\title{
La strada come architettura. Le vie colonnate nelle terre di Efeso, Jerash, Petra e Palmira. Appunti per una rappresentazione
}

\author{
Francesco Trimboli
}

\section{Abstract}

L'obiettivo della ricerca presentata è quello di indagare le caratteristiche morfo-genetiche delle città di fondazione ellenistico-romana in Siria, attraverso la ri-lettura delle tracce lasciate dalle vie colonnate, l'elemento a scala urbana tipico dell'urbanistica romana in questa regione. Un lavoro come sintesi morfologica dei segni sedimentati in queste terre, che identifica nella rappresentazione lo strumento e il metodo, narrativo e diagnostico, con cui analizzare, scomporre e codificare questi congegni colonnati. Gli esempi proposti insistono sui princìpi della forma, nel tentativo di descrivere la morfogenesi della matrice di questi impianti e di come, questa, verrà assunta come modello urbano, come paradigma di un sistema architetturale contemporaneo. Un ri-disegno che consente di decodificare un linguaggio perduto, l'impronta materica del deserto che diventa memoria.

Viene restituita una visione fenomenologica di ciò che resta, essenza silenziosa, muta, eterna, il cui valore iconografico è l'espressione più intima della cultura del tempo che li ha prodotti.

Parole chiave

archetipo, modello, rappresentazione, memoria, deserto.

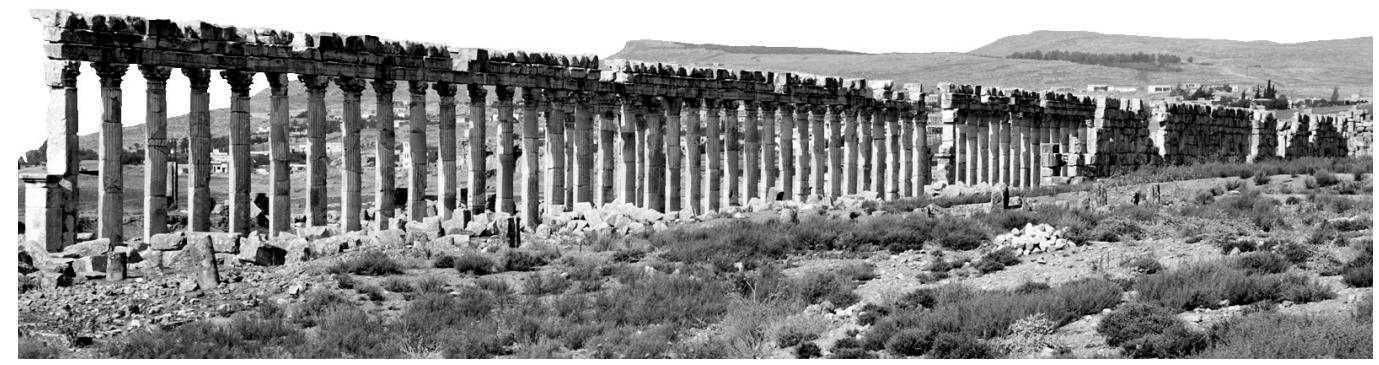


II seguente lavoro propone una rilettura della matrice architettonica, quale genesi di un sistema che ha caratterizzato l'impianto urbano delle città di fondazione ellenistico-romana [I]. Si tratta di una trascrizione fatta di segni, di forme ri-disegnate in cui le tracce di queste città diventano memoria prima ancora di ri-diventare deserto. In particolare, la rappresentazione modellistica e la simulazione grafica diventano uno strumento per la conoscenza che tende al recupero della memoria morfologica di questi luoghi.

II lavoro proposto affida alla rappresentazione una funzione psichica nel tentativo di riprodurre nella mente l'esperienza passata, riconoscerla come tale e localizzarla nello spazio e nel tempo, attraverso immagini che decostruiscono il significato dell'opera architettonica riconducendola ad un modello primitivo fatto di sabbia prima ancora di diventare segno; si propone dunque, come riscrittura architettonica dei segni impressi nel suolo. Un lavoro che non mira alla archeologia, ma un lavoro di ri-lettura, dove queste tracce definiscono un vocabolario di strutture esse stesse narrative (fig. I).

Fig. I. Per una analisi. Logotipo delle città di Apamea, Antiochia, Jerash A Palmira (elaborazione e Palmira (elaborazione grafica di Francesco Trimboli).
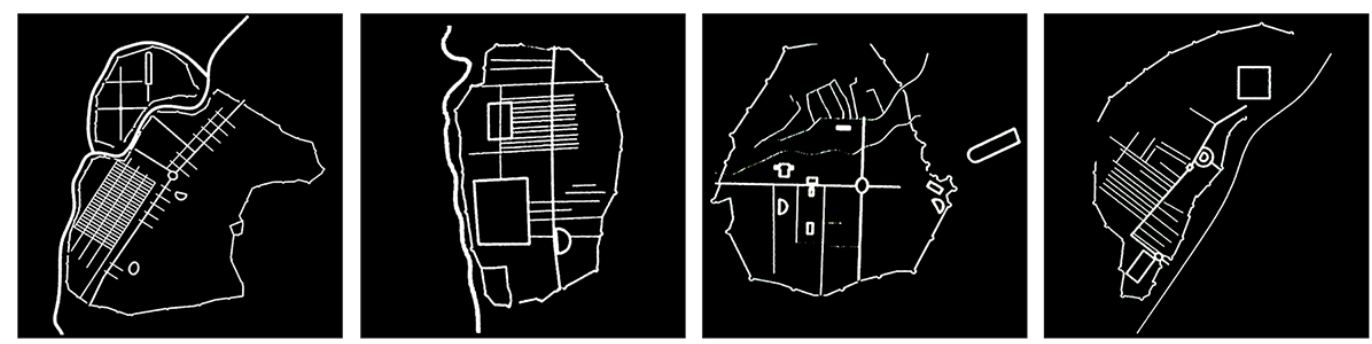

Ciò che emerge da questa ricerca è che fra gli esempi proposti, le tracce lasciate dalle vie colonnate sembrano avere tutte una stessa matrice comune, una memoria della matrice, che diventa essa stessa patrimonio genetico dell'architettura come unico significato globale fatto di singoli elementi formali che la ricostruiscono idealmente all'interno di una idea di città [Ginex 20I I].

Emerge una nuova identità del luogo ri-disegnata attraverso i segni impressi sul terreno, tracce che denotano un paesaggio dalla forma autonoma in nuovi contesti di rovine, figure nuove ancora da decifrare la cui rappresentazione non tende al virtual landscape ma piuttosto al tentativo di ripristinare la memoria di questi luoghi, in quello che potremmo definire alfabeto morfologico.

Attraverso la ri-lettura di questi segni, i quali assumono un valore narrativo intrinseco tra paradigma ed archetipo configurativo [2] quale valore reale dato dalla materia di cui è fatto, si può giungere alla conclusione che la forma di queste città colonnate di fondazione ellenistico-romana in Siria, si discosta dalla idea di città pianificata frutto di un intervento progettuale in relazione allo spazio antropico circostante, si configura invece come impianto geometrico all'interno del territorio senza mai entrare formalmente in relazione con esso. Analizzando il tessuto urbano emerge che queste apparenti irregolarità sono dettate dalla volontà di seguire le direttrici principali del territorio e che la via colonnata, l'elemento a scala urbana tipico dell'urbanistica romana in questa regione, rappresenti il vincolo di connessione tra le strutture urbane pianificate secondo giaciture differenti [Neglia 20I9] (fig. 2). L'impianto urbano degli insediamenti siriani in epoca ellenistica, monoassiale con gli isolati che si attraversavano prevalentemente con il lato lungo in direzione nord-sud, è caratterizzato da una forma chiusa compatta con poche relazioni con il territorio circostante, il motivo potrebbe ricondursi a ragioni di difesa, dove un circuito di mura difensive rappresentava il sistema difensivo collegato alla cittadella fortificata che riceve la sua forma dal deserto a cui si oppone [Calvino 1972], un recinto, un archetipo dentro un archetipo.

Le mura rappresentano quindi il legame della città con il sito, fungendo da proseguimento antropico della struttura naturale del suolo, adattando il proprio andamento a quello dell'oreografia, divenendo piano quando questa era, appunto, piana. 
Un dispositivo spaziale che funziona come un congegno che, attraverso l'assemblaggio delle sue parti, diventa sintesi ed esito di un progetto di riconoscimento ottenuto attraverso la sua rappresentazione e il ri-disegno della struttura.

L'elemento colonna diventa un sistema che si riproduce in un elevato numero di esemplari morfologici che assumono il ruolo di modelli urbani che si ripetono attraverso regole di aggregazione e che hanno in ultimo un carattere inconfondibile e identitario [Ginex 20 I7]. L'impronta architettonica di queste città, natura e artificio, appare oggi perduta, memoria che diventa sabbia, come il caso di Palmira, sposa che diventa deserto. L'interpretazione formale e strutturale delle vie colonnate tende alla ricostruzione mimetica della forma originaria nel tentativo di fare emergere il gene che caratterizza l'impianto.

La matrice di fondo andrebbe ricercata, in generale, nel modello della stoà ellenistica, nella definizione dello spazio pubblico ornamentale fulcro per lo svolgimento sociale e politico nella vita dei cittadini.

La lettura di questi tessuti residuali, negli esempi proposti ci permette di osservare come tale matrice sarà associata alla operazione di monumentalizzazione urbana ed edilizia, dove la costruzione del cardo e del decumano come strada colonnata e l'introduzione degli archi di trionfo lungo il percorso hanno rappresentato l'adozione di elementi che marcano il ritmo del passaggio tra un quartiere e l'altro della città, dettato dalla continuità, se non addirittura dalla crescita, della pressione commerciale sullo spazio.

Questo porterà alla disgregazione e alla razionalizzazione della struttura dello spazio urbano, riflesso di dinamiche sociali in senso più ampio [Cabiale 2013, pp. 321-336].
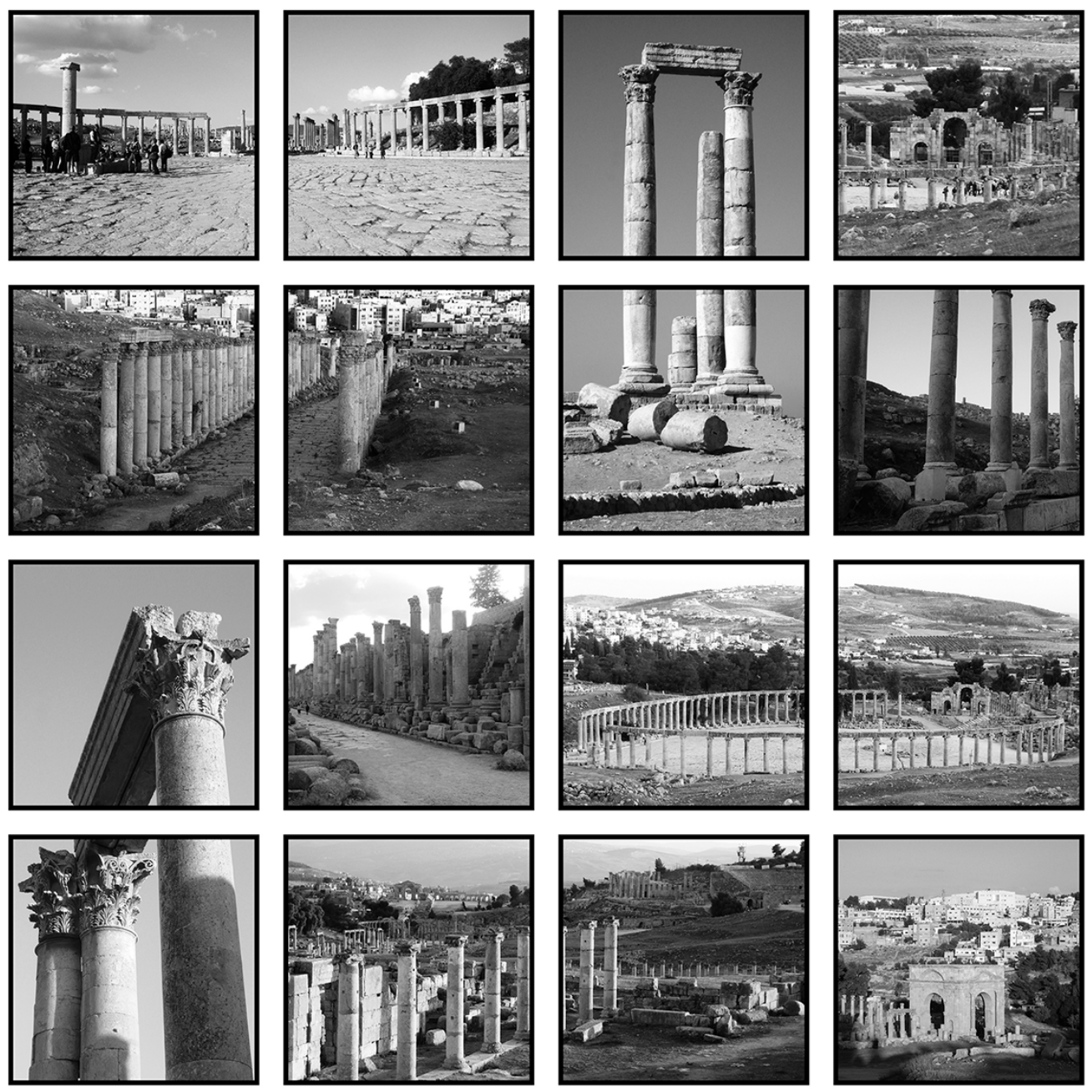
In un primo momento, la via colonnata nasce, quindi, come opera che, in riferimento alla stoà, andrà a disegnare il perimetro dell'agorà o del mercato, come nel caso di Efeso ad esempio, dove la pianificazione ortogonale delle vie permette di creare delle agorà chiuse, in cui la monumentalizzazione di questi spazi è affidata alla costruzione delle stoà, attraverso la quale inizia a proiettarsi un nuovo modello di spazio pubblico (fig. 3). Aspetto non trascurabile, e che si ripercuoterà sulla fisiognomica delle vie colonnate è il fatto che la stoà delimita sì uno spazio, ma non lo isola rispetto gli impianti urbani. Lo sviluppo economico di queste città, determinato dagli scambi commerciali farà mutare l'impianto tipologico di questi spazi in quello che potremmo definire la commercializzazione dello spazio, che porterà alla definizione di nuove idee spaziali e architettoniche che porteranno alla definizione di nuovi spazi commerciali, i bazaar [Rostovztff 20 I].

Successivamente viene assunto un modello intermedio il cui scopo si riconduce esclusivamente alla sola monumentalizzazione di un tratto sacro, quasi a volere sottolineare l'importanza di un percorso, la sacralità di un cammino. II caso di Petra (fig. 4) diventa esplicativo, poiché alla nomina di capitale della provincia di Arabia, l'impianto urbano che si sviluppava su una pianta oblunga, viene assorbito dalla costituzione di un colonnato in un intervento architettonico unitario [Cerasi 2005].

Questa astrazione diventa tangibile quando il tratto colonnato sorge in maniera indipendente rispetto alle architetture che sorgono sul territorio. Sarà questa astrazione che farà assumere al tratto colonnato, cardo e decumano, caratteri rappresentativi volti a dimostrare

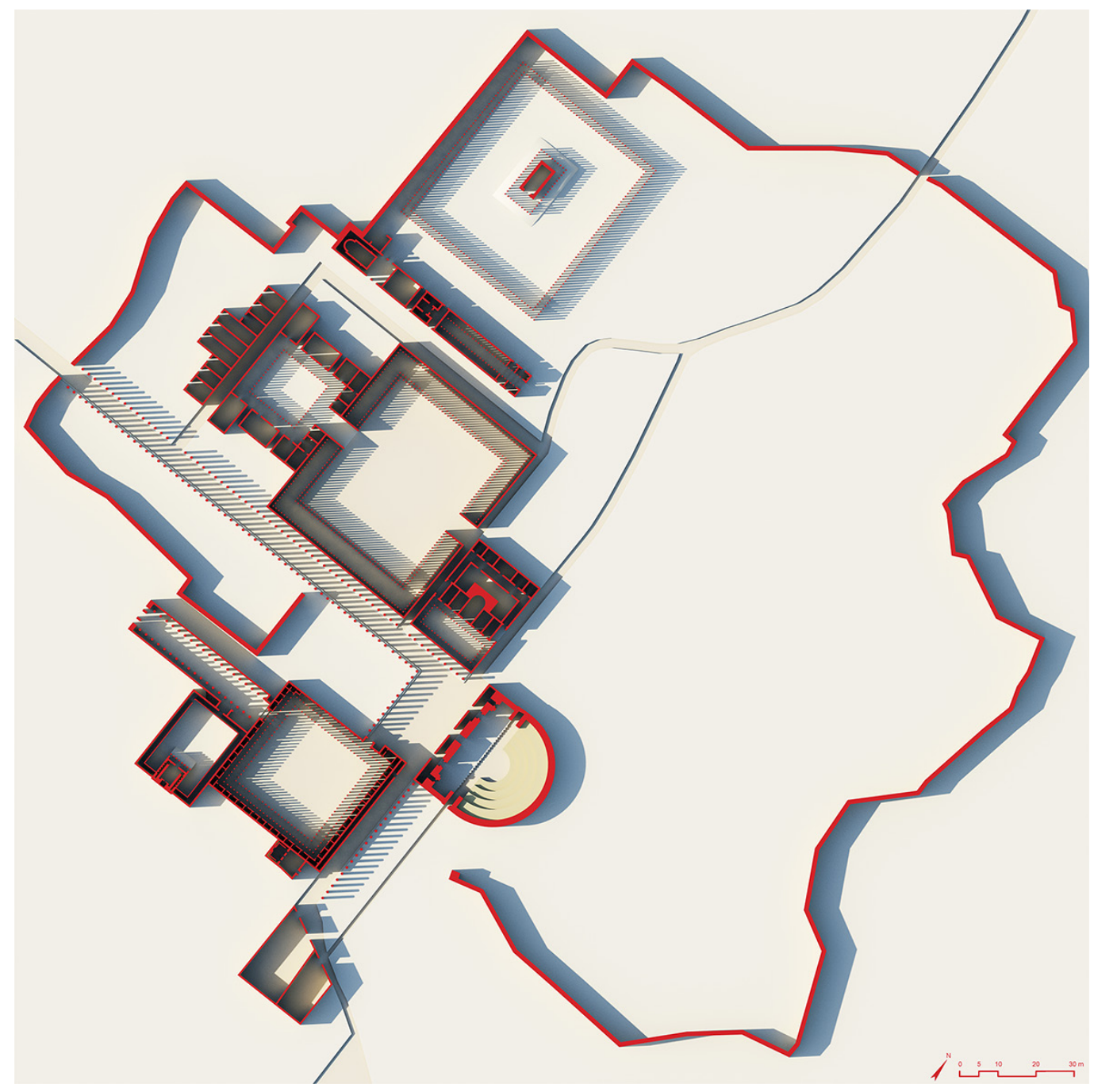


lo splendore della città in cui esso emerge, non costituendo più un percorso indipendente, ma un percorso che si fonda con le architetture presenti.

La commercializzazione dello spazio consentirà a città come Jerash (fig. 5) di intervenire sulla propria forma urbana per momenti consequenziali, in linea con lo spirito del tempo, di conseguenza strade e piazze vengono occupate in diversi momenti a testimonianza del fatto che si assiste ad una nuova ripartizione dello spazio, che esula da fattori funzionali ed economico-commerciali [Brenk 2007, pp. 173-185].

Riferendoci sempre a Jerash, si veda comunque come i diversi scavi archeologici, testimoniano il tentativo di regolarizzazione dello spazio, la volontà di superare il dualismo strada ed architettura. Scomparirà la linea di demarcazione tra strada ed architettura, ma le architetture diventano strade e le strade colonnate architetture. Nel punto di intersezione tra cardo e decumano, si apre una piazza ovale a cui è affidato il compito di ri-disegnare lo spazio pubblico, un approccio che dimostra un maggiore controllo, l'idea di definire un modello morfologico che colloca le unità commerciali entro gli spazi urbani mantenendo comunque i caratteri della stoà.

La disamina di questi paradigmi morfologici consente di definire come a Palmira (fig. 6), entrando dalla porta di Damasco, la via colonnata diventa una piazza ovale, colonnata, che insieme alla porta e alla successiva via, anch'essa delimitata da colonne, costituisce un intervento architettonico unitario. Palmira si sviluppa su schemi e funzioni già consolidate [De Micheli 200 I, p. 57] dove il ritmo scandito delle colonne, nell'alternanza dei pieni e dei

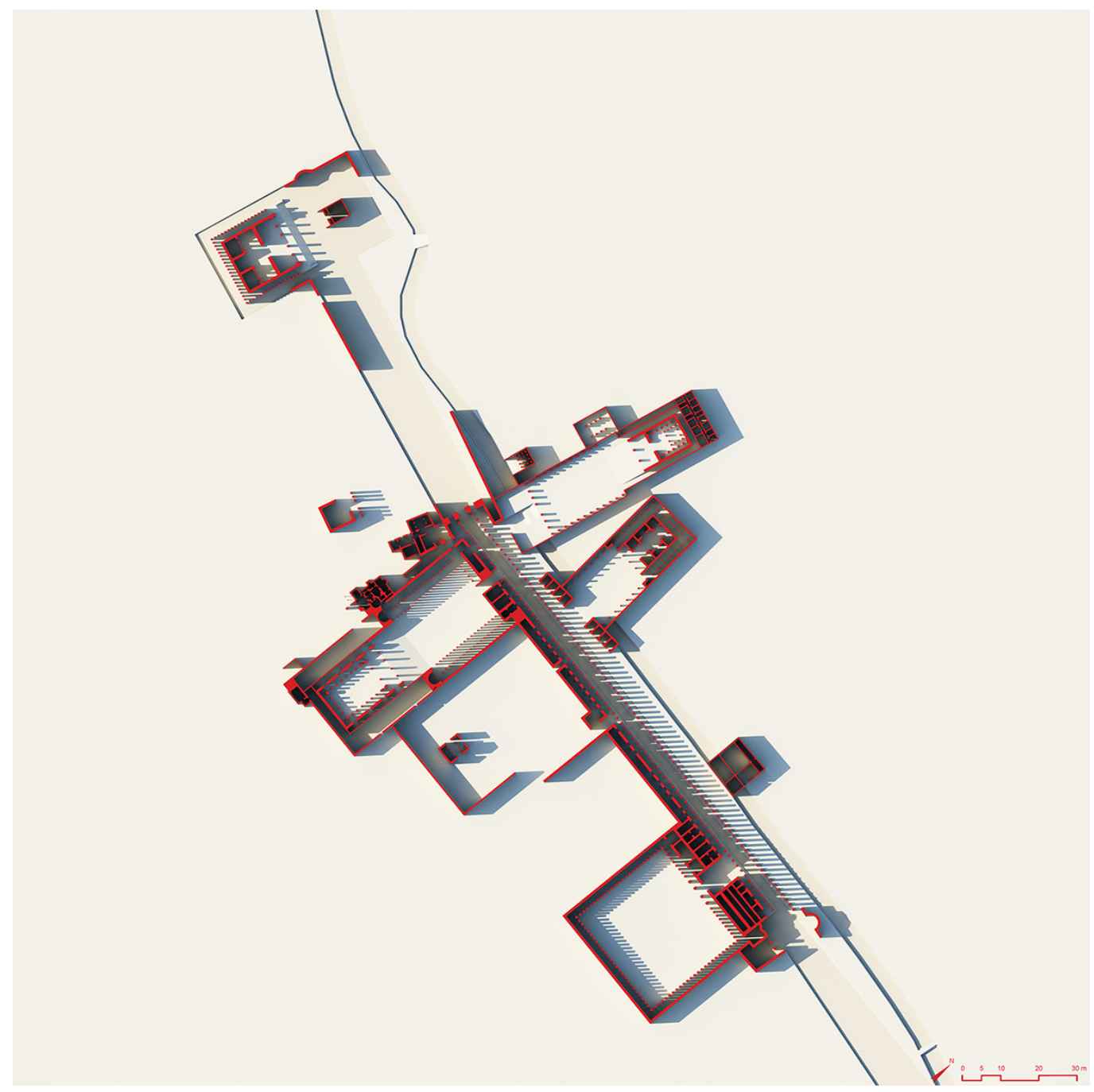


Fig. 5. Per un modello: Jerash (elaborazione grafica di Francesco Trimboli).
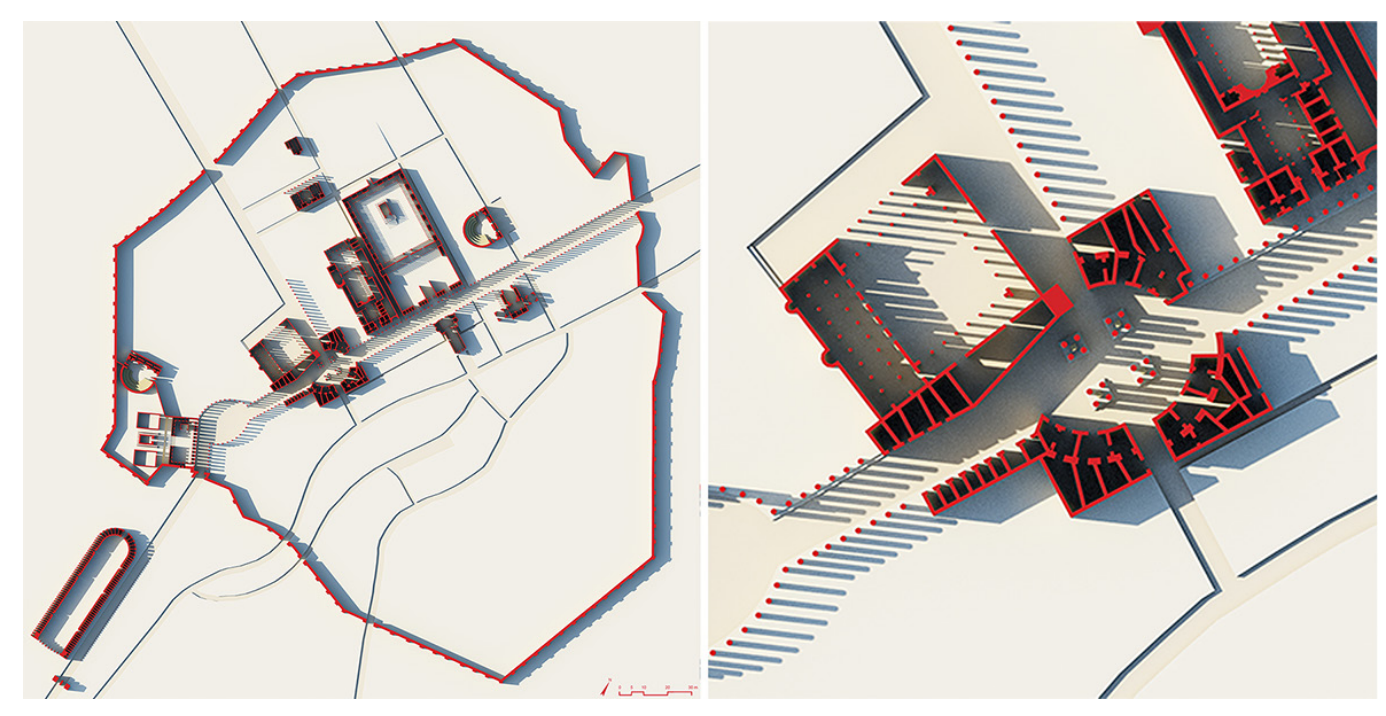

Fig. 6. Per un modello: Palmira (elaborazione grafica di Francesco Trimboli).

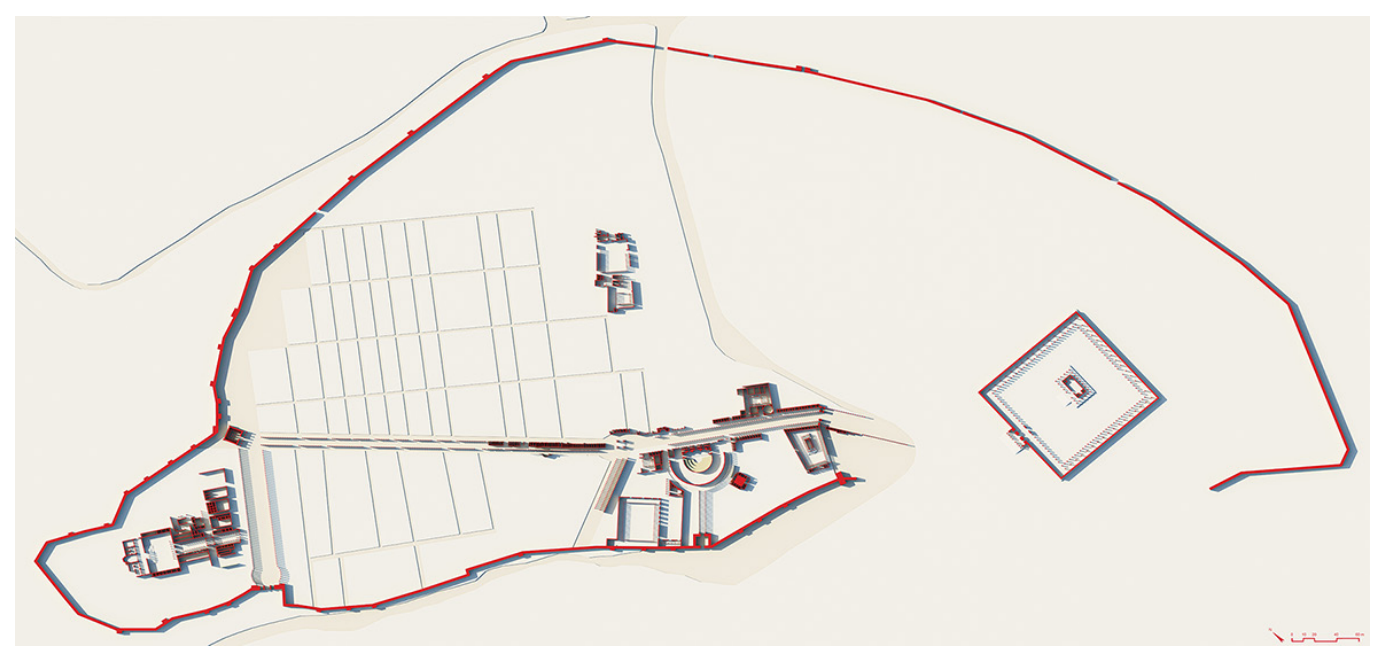

Fig. 7. Per una narrazione Modelli tridimensionali,
come narrazione morfocome narrazione morfo-
genetica del tratto colongenetica del tratto colon-

nato nelle città di Efeso,

Petra, Jerash e Palmira

(elaborazione grafica di
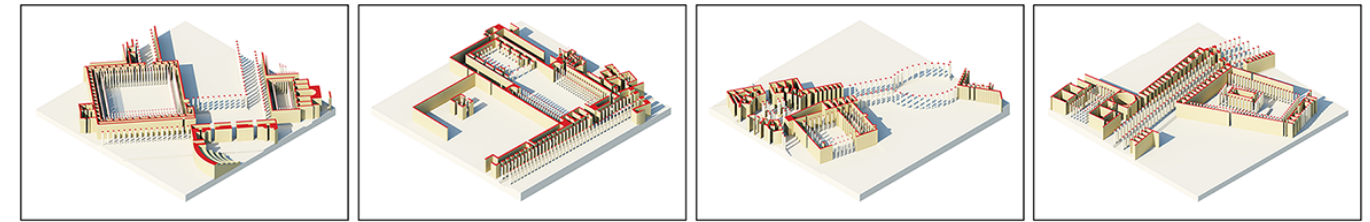
vuoti rende la via architettonicamente omogenea, senza che vi fossero elementi emergenti o di particolare monumentalità. II colonnato diventa l'elemento di controllo della morfologia urbana, che non si erge in maniera improvvisa alterando l'identità originaria del luogo, è il deserto che si fa materia. Di conseguenza il tessuto morfologico non è più luogo caratterizzato da una architettura esigenziale ma luogo esperienziale dove un congegno colonnato anima la scena urbana [Branzi 2007, p. 46] (fig. 7).

Scena che può essere narrata attraverso dei frame, uno storyboard che ripercorre il ritmo scandito dalle colonne e che diventa lo strumento tangibile con cui scansionare le tracce visibili di una architettura che si fa memoria, appunti per una rappresentazione (fig. 8).

La ri-scrittura architettonica proposta in questo lavoro si può ricondurre alla trascrizione formale di città che oggi si presentano come una sorta di residuo della forma originaria che si concretizza solo, ormai, attraverso i ruderi che consentono di ri-costruire la completezza del disegno urbano.
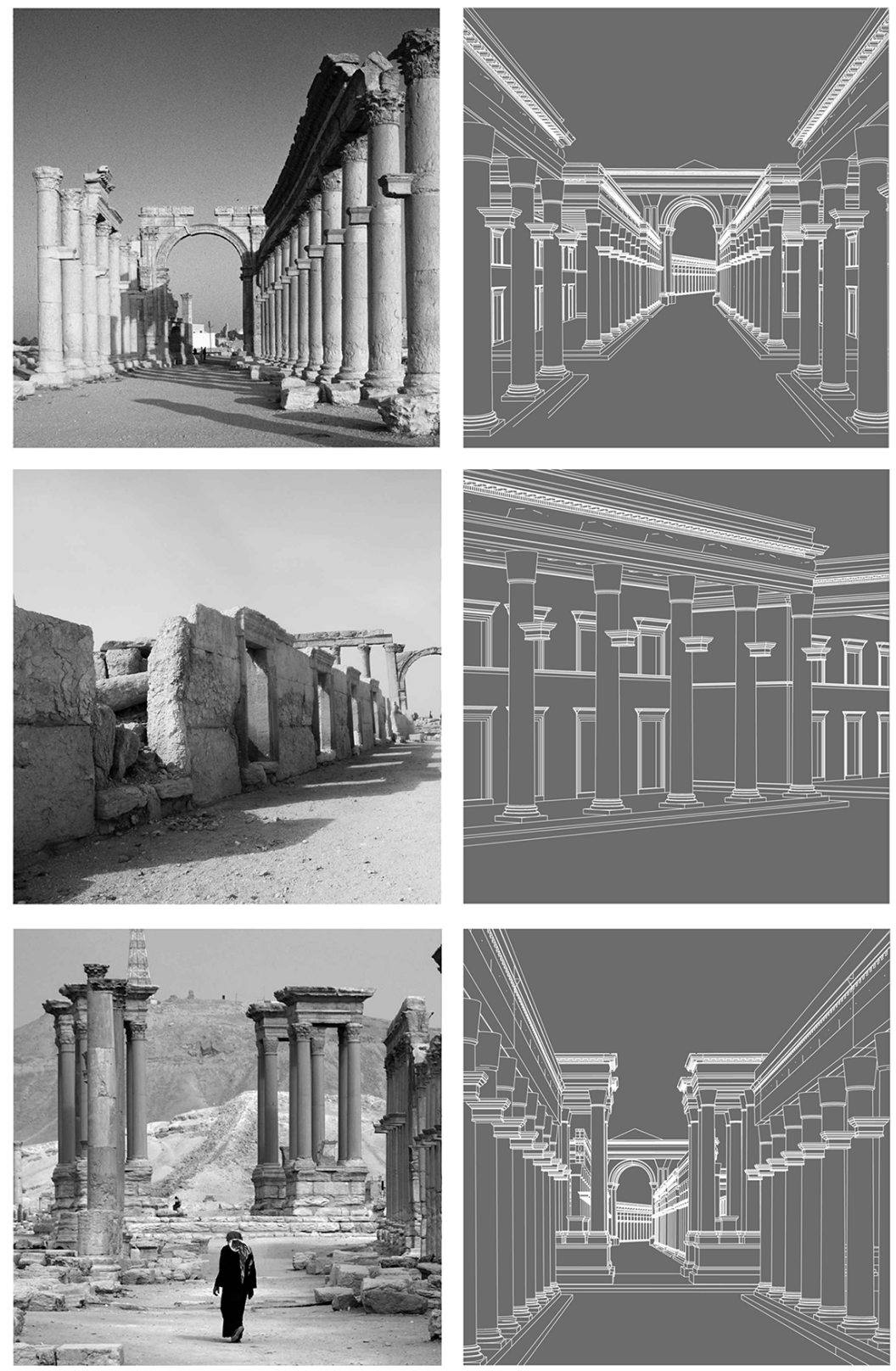
Segno che si fa memoria. II disegno come strumento formale a cui riconoscere la capacità di interrogarsi sui temi della progettazione. II disegno come progetto. Ė questo lo scopo del lavoro presentato, riflettere su temi che stanno scomparendo per mettere in luce, attraverso una rappresentazione iconica (fig. 9) la sintesi morfologica dei caratteri che costituiscono questi tessuti urbani, la cui permanenza costituisce l'elemento principale di continuità con l'età romano-bizantina [Arce 2006], miraggio di tutte le caratteristiche della visione [Branzzi 2007].
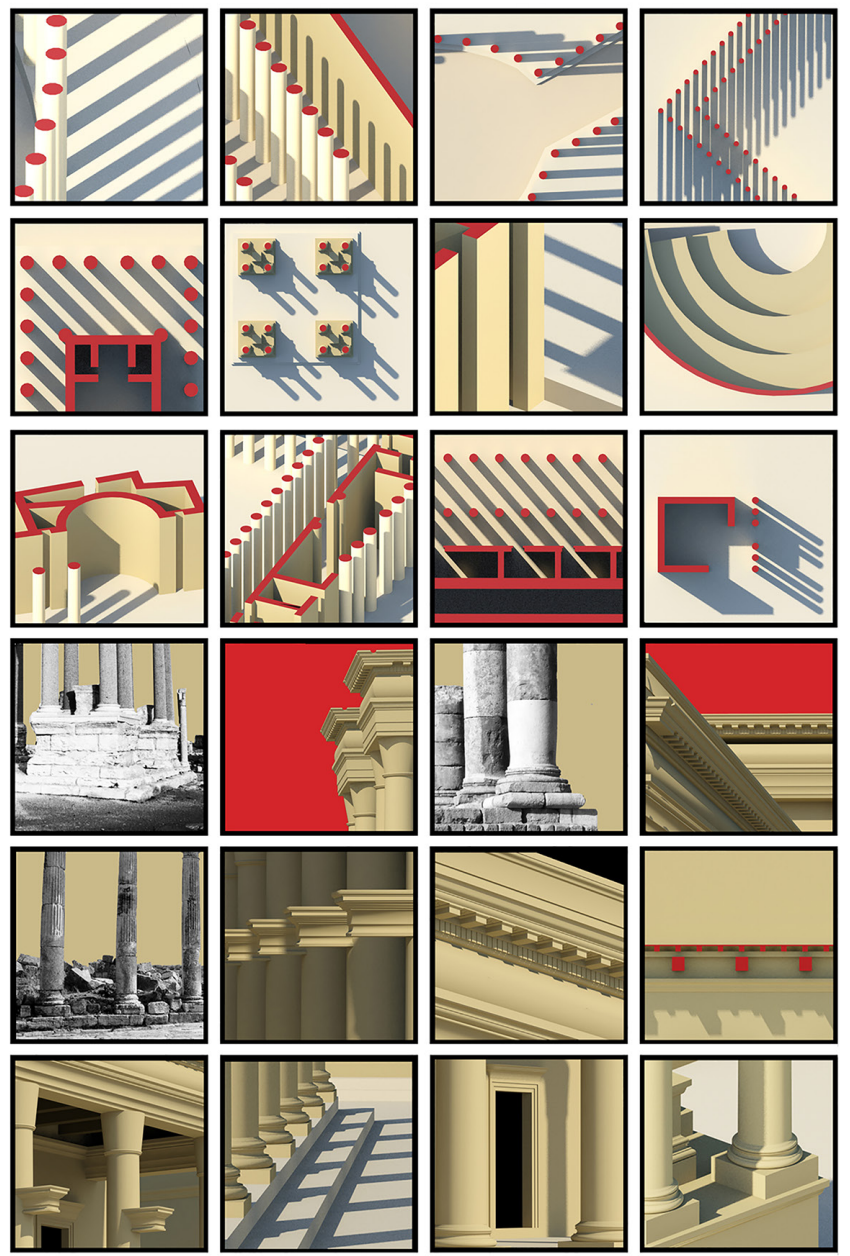

Fig. 9. Per una memoria.
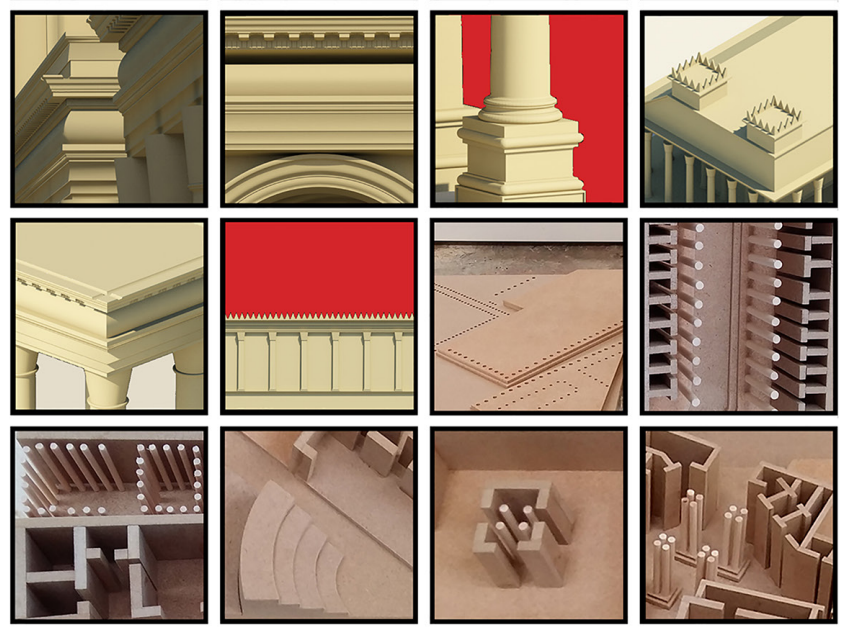


\section{Note}

[I] II tema presentato è stato sviluppato in una prima analisi nella Tesi di Laurea dell'autore, Francesco Trimboli La strada come architettura. Le vie colonnate nelle terre di Efeso Jerash, Petra e Palmira. Laurea Magistrale in Architettura e Ingegneria Edile LM-4, discussa nell'anno accademico 2015-2016 presso l'Università degli Studi Mediterranea di Reggio Calabria, di cui relatore Prof. Arch. Gaetano Ginex.

[2] "L'analisi dell'idea formalizzata, la sua scomposizione, la sua visione da ogni punto di vista reale e irreale, il suo attraversamento e la contemporanea indagine di più punti tra loro non contigui e non visibili" (M.S. 2007), è ciò che la rende significativa. Un susseguirsi di elementi che come sineddoche si avviano a dare degli esiti formali miracolosamente "banali", ma pur sempre rappresentativi di un idea" [Ginex 20II].

\section{Riferimenti bibliografici}

Arce Ignacio (2006), Umayyad Arches,Vaults and Domes: Marging and Re-Creation. Contributions to Early Islamic Construction History. In Dunkeldt Malkom et al. (eds). Proceeding of the Second Internetional Confress on Construction History. Exter: Cambrige Editions, vol. I, pp. 195-220.

AA.W. (20|4). Palmira: impianto urbano, via colonnata e ninfeo B. Lecce:Youcanprint.

Bejor Giorgio (1999). Vie Colonnate. Paesaggi urbani del mondo antico. Roma: Giorgio Bretschneider Editore.

Branzi Andrea (2007). Dall'arredo alla scenografia urbana. In Brazi Andrea. Capire il design. Firenze: Giunti editore.

Cabiale Valentina (20II). La lunga durata delle vie colonnate nella regione siro-palestinese. Dai Bizantini agli Omayyad. In Archeologia Medievale, XL, 2013 - Fortificazioni di terra in Italia. Motte, tumuli, tumbe, recinti. Atti del Convegno, Scarlino, I 4- I6, pp. $321-330$.

Calvino Italo (1972). Le città invisibili.Torino: Einaudi.

Cerasi Maurice (2005). La città dalle molte culture: l'architettura nel Mediterraneo orientale. Limena: Libri Scheiwiller.

Ginex Gaetano (20l I). Strutture Formali e Alfabeti compositivi. Impianti urbani romani nelle regioni desertiche del Mediterraneo. Progetto di un sistema interattivo per la conoscenza e la gestione del patrimonio culturale del Mediterraneo. In Giovannini Massimo, Prampolini Franco ( cura di). Spazi e Culture del Mediterraneo 3. Reggio Calabria: Centro Stampa d'Ateneo, pp. 30I-320.

Ginex Gaetano (20 I I), Progettare con gli archetipi. In AAV. Le città del Mediterraneo. Atti del IV Forum Internazionale di Studi, Reggio Calabria giugno 20 I I. Reggio Calabria: liriti Editore.

Ginex Gaetano (2017). Nefta e le città oasi di Nefta, Tamerza, Mides e Chebika. Reggio Calabria: Iriti editore, Reggio Calabria.

Neglia Giulia Annalinda (2009). Medina. Saggi sui paesaggi urbani delle città del Mediterraneo sud-orientale. Bari: Polibarpress AGF.

Rostovtzeff Michail (20। I). Città carovaniere. Roma: Pgreco.

Brenk Beat (2008), The end of the Roman temple I73- I 85 and the end of the Chatedral church of Jerash. In Farioli Campanati $\mathrm{R}$. et al. (a cura di), Ideologia e cultura artistica tra Adriatico e Mediterraneo orientale (IV-X secol). II ruolo dell'autorità ecclesiastica alla luce di nuovi scavi e ricerche. Atti del Convegno Internazionale. Bologna - Ravenna, 26-29 novembre 2007. Bologna: Ante Quem.

\section{Autore}

Francesco Trimboli, Università degli Studi Mediterranea di Reggio Calabria, francesco.trimboli@unirc.it

Per citare questo capitolo: Trimboli Francesco (2020). La strada come architettura. Le vie colonnate nelle terre di Efeso, Jerash, Petra e Palmira. Appunti per una rappresentazione/The street as architecture. The colonnaded streets in the lands of Ephesus, Jerash, Petra and Palmyra. Notes for a representation. In Arena A., Arena M., Brandolino R.G., Colistra D., Ginex G., Mediati D., Nucifora S., Raffa P. (a cura di). Connettere. Un disegno per annodare e tessere. Atti del $42^{\circ}$ Convegno Internazionale dei Docenti delle Discipline della Rappresentazione/Connecting. Drawing for weaving relationships. Proceedings of the 42th International Conference of Representation Disciplines Teachers. Milano: FrancoAngeli, pp. $2803-2820$. 


\title{
The Street as Architecture. The Colonnaded Streets in the Lands of Ephesus, Jerash, Petra and Palmyra. Notes for a Representation
}

\author{
Francesco Trimboli
}

\section{Abstract}

The objective of the research presented is to investigate the morpho-genetic characteristics of the Hellenistic-Roman cities of foundation in Syria, by re-reading the traces left by the colonnaded streets, the urban scale element typical of Roman urban planning in this region. A work as a morphological synthesis of the signs settled in these lands, which identifies in the representation the instrument and the method, narrative and diagnostic, with which to analyze, decompose and codify these colonnaded devices. The proposed examples insist on the principles of form, in an attempt to describe the morphogenesis of the matrix of these systems and how this will be taken as an urban model, as a paradigm of a contemporary architectural system. A re-drawing that allows you to decode a lost language, the material imprint of the desert that becomes memory. A phenomenological vision of what remains is returned, silent, silent, eternal essence, whose iconographic value is the most intimate expression of the culture of the time that produced them.

Keywords

archetype, model, representation, memory, desert.

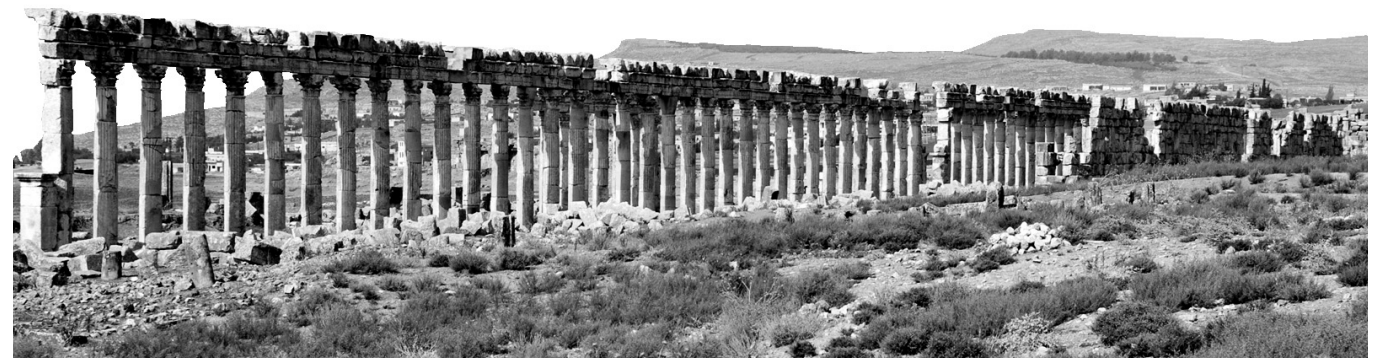


The following work proposes a re-reading of the architectural matrix, as the genesis of a system that characterized the urban layout of the Hellenistic-Roman foundation cities [ $\mathrm{I}$ ]. It is a transcription made of signs, of re-drawn forms in which the traces of these cities become memory before they even become desert again. In particular the modelling representation and the graphical simulation become a tool for the acquaintance that tends to the recovery of the morphological memory of these places.

The proposed work entrusts to the representation a psychic function in an attempt to reproduce in the mind the past experience, recognize it as such and locate it in space and time, through images that deconstruct the meaning of the architectural work leading it back to a primitive model made of sand before it even becomes a sign; it is proposed, therefore, as an architectural rewriting of the signs engraved in the ground. A work that does not aim at archaeology, but a re-reading work, where these traces define a vocabulary of structures themselves narrative (fig. I).

Fig. I. For an analysis. Logotype of the cities of Apamea, Antioch, Jerash and Palmira (graphic elaboration by Francesco Trimboli).
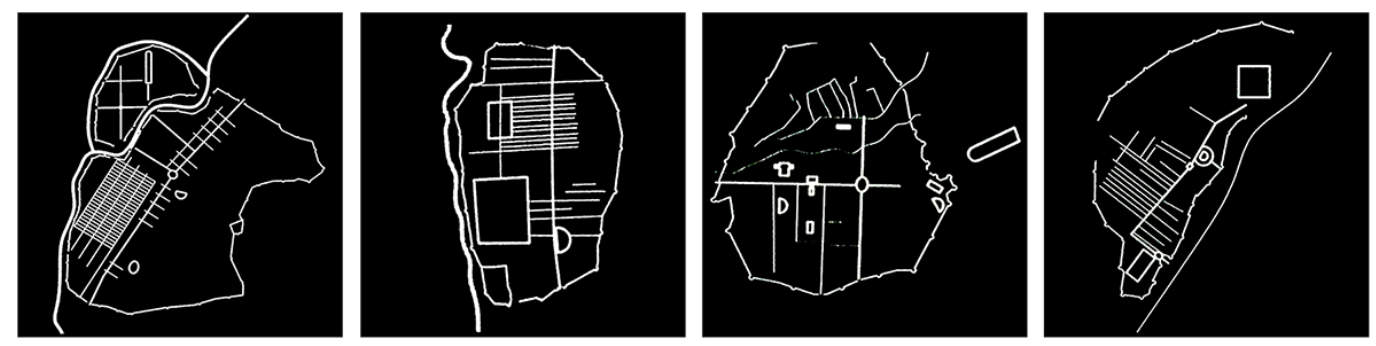

What emerges from this research is that among the proposed examples, the traces left by the colonnaded streets all seem to have the same common matrix, a memory of the matrix, which itself becomes the genetic heritage of architecture as the only global meaning made up of individual formal elements who ideally reconstruct it within an idea of the city [Ginex 20II].

A new identity of the place emerges re-drawn through the signs imprinted on the ground, traces that denote a landscape from the autonomous form in new contexts of ruins, new figures still to be deciphered whose representation does not tend to the virtual landscape but rather to the attempt to restore the memory of these places, in what we could define morphological alphabet.

Through the re-reading of these signs, which assume an intrinsic narrative value between paradigm and configurative archetype [2] as the real value given by the matter of which it is made, it can be concluded that the form of these colonnaded cities of Hellenistic-Roman foundation in Syria deviates from the idea of a planned city resulting from a design intervention in relation to the surrounding anthropic space, is instead configured as a geometric system within the territory without ever formally entering into relationship with it. Analyzing the urban fabric it emerges that these apparent irregularities are dictated by the will to follow the main directions of the territory and that the colonnade street, the urban element typical of the Roman urbanism in this region, represents the connection constraint between urban structures planned according to different layers [Neglia 2019] (fig. 2).

The urban layout of the Syrian settlements in the Hellenistic era, monoaxial with the blocks that were mainly crossed with the long side in the north-south direction, is characterized by a closed compact shape with few relations with the surrounding territory, the reason could be traced to reasons of defense, where a circuit of defensive walls represented the defensive system connected to the fortified citadel that receives its form from the desert to which it opposes [Calvino 1972], a fence, an archetype inside an archetype.

The walls therefore represent the city's link with the site, acting as an anthropic continuation of the natural structure of the soil, adapting its development to that of the oreography, becoming flat when this was, precisely, flat. 
A spatial device that functions as a device that, through the assembly of its parts, becomes the synthesis and outcome of a recognition project obtained through its representation and re-drawing of the structure.

The column element becomes a system that reproduces in a large number of morphological specimens that assume the role of urban models that are repeated through aggregation rules and that ultimately have an unmistakable and identity character [Ginex 20 I7].

The architectural imprint of these cities, nature and artifice, appears lost today, memory that becomes sand, like the case of Palmyra, bride that becomes desert. The formal and structural interpretation of the columns tends to the mimetic reconstruction of the original form in an attempt to bring out the gene that characterizes the system.

The basic matrix should be sought, in general, in the model of Hellenistic stoà, in the definition of the ornamental public space fulcrum for the social and political development in the life of citizens.

The reading of these residual fabrics, in the proposed examples allows us to observe how this matrix will be associated with the operation of urban monumentalization and building, where the construction of the thistle and decumanus as a colonnaded road and the introduction of the triumphal arches along the route represented the adoption of elements that mark the rhythm of the passage between one district and the other of the city, dictated by continuity, if not even by growth, commercial pressure on space.

This will lead to the disintegration and rationalization of the structure of the urban space, a reflection of social dynamics in a broader sense [Cabiale 2013, pp. 321-336].
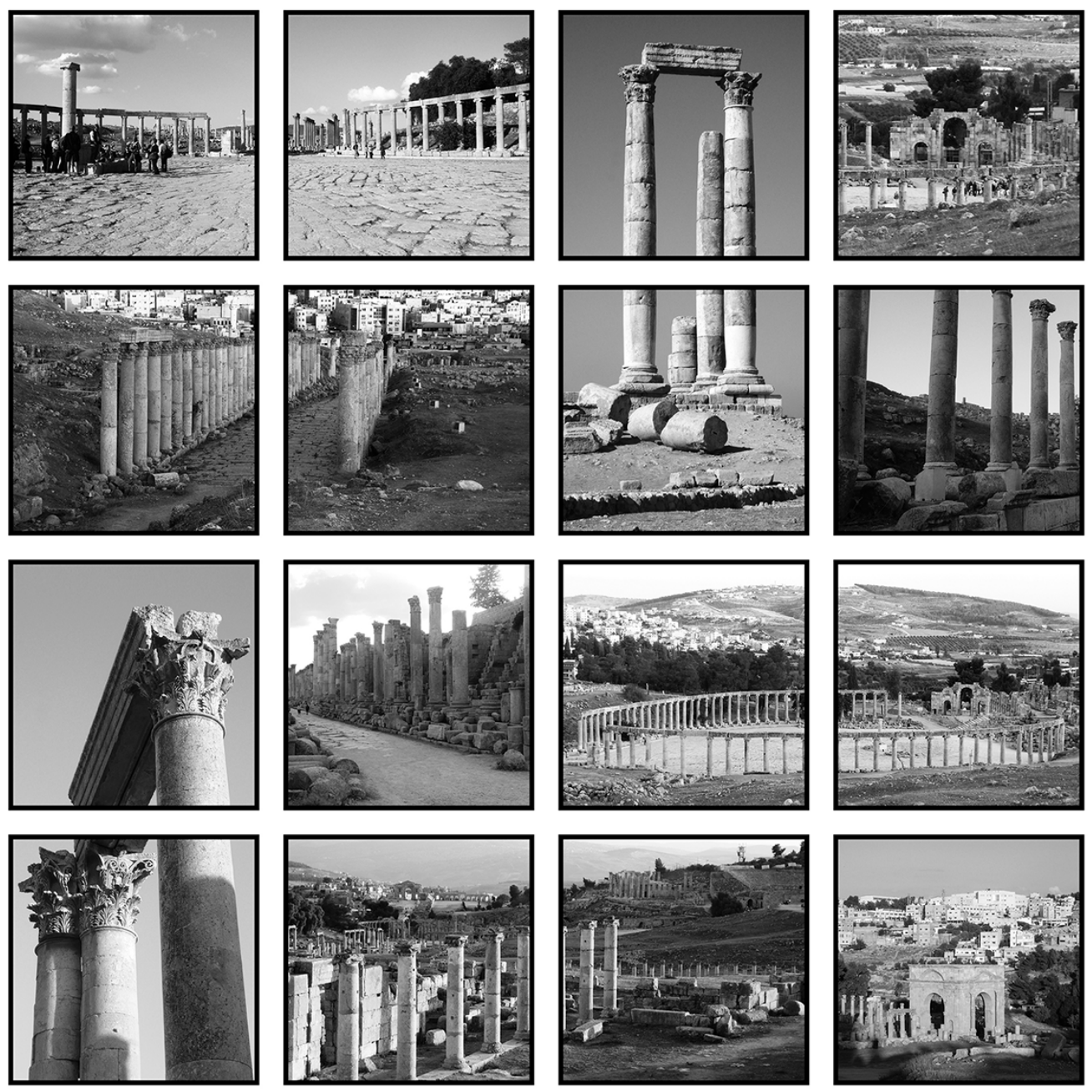
At first, the colonnaded street was born, therefore, as a work that, in reference to the stoà, will go to draw the perimeter of the agorà or the market, as in the case of Ephesus for example, where the orthogonal planning of the streets allows you to create of the closed agorà, where the monumentalization of these spaces is entrusted to the construction of the stoà, through which a new model of public space begins to project itself (fig. 3). A not negligible aspect, which will have an impact on the physiognomy of the colonnaded streets is the fact that the stoà defines a space, but does not isolate it from urban systems. The economic development of these cities, determined by commercial exchanges, will change the typological layout of these spaces into what we might call the commercialization of space, which will lead to the definition of new spatial and architectural ideas that will lead to the definition of new commercial spaces, the bazaar [Rostovztff 20I].

Subsequently, an intermediate model is taken whose purpose is exclusively due to the monumentalization of a sacred trait, as if to underline the importance of a path, the sacredness of a path. The case of Petra (fig. 4) becomes explanatory, as with the appointment of the capital of the province of Arabia, the urban layout that developed on an oblong plan was absorbed by the creation of a colonnade in a unitary architectural intervention [Cerasi 2005]. This abstraction becomes tangible when the colonnade stretch rises independently from the architectures that arise in the area. It will be this abstraction that will cause the colonnade, cardo and decumanus to take on representative characters aimed at demonstrating the splendor of the city in which it emerges, no longer constituting an independent path, but a path that is based on the architecture present.

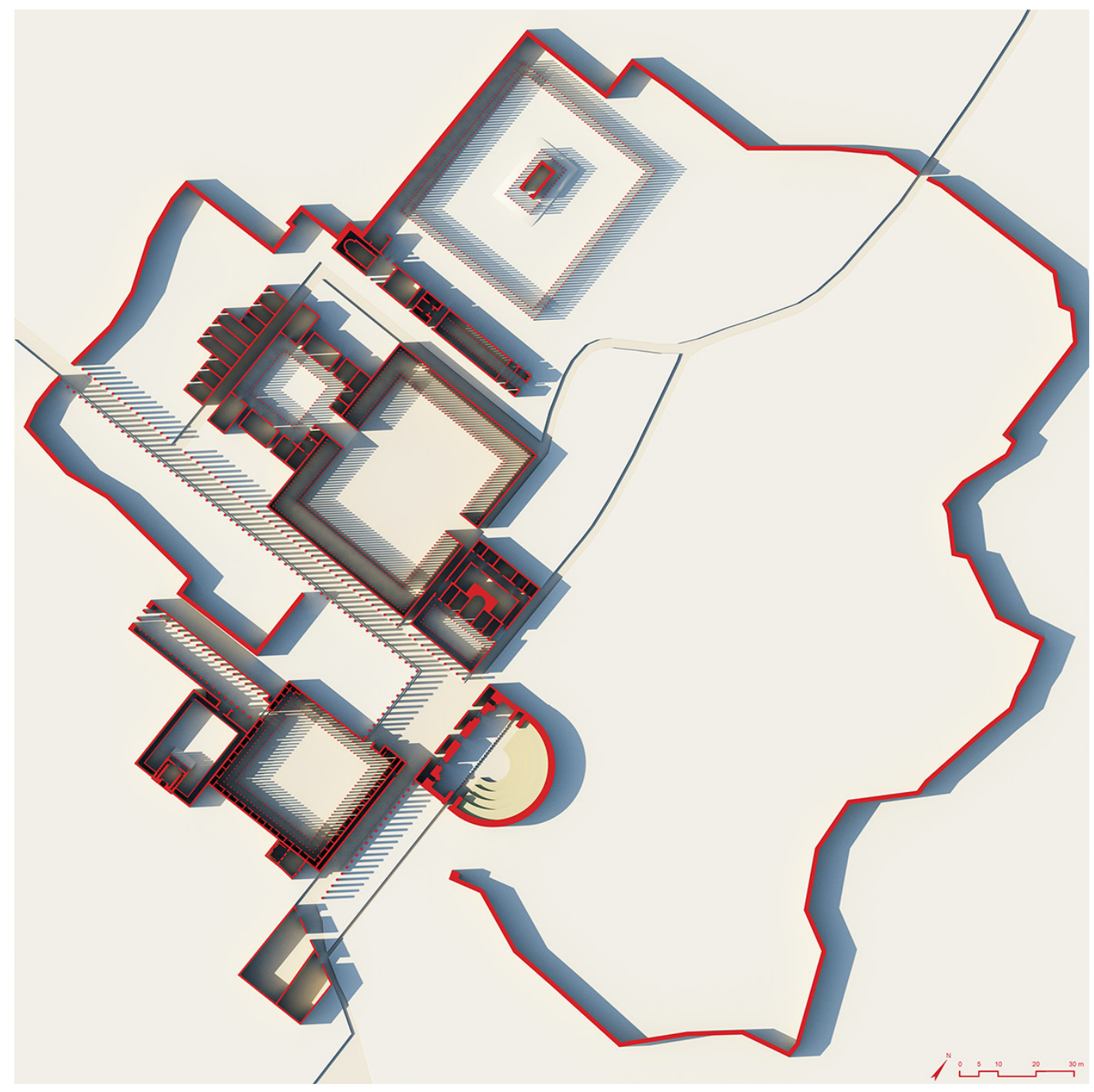


The commercialization of the space will allow cities such as Jerash (fig. 5) to intervene on their urban form for consequential moments, in line with the spirit of the time, as a result streets and squares are occupied at different times as evidence of the fact that we are witnessing a new division of space, which goes beyond functional and economic-commercial factors [Brenk 2007, pp. 173-185].

Always referring to Jerash, however, see how the various archaeological excavations testify to the attempt to regularize the space, the desire to overcome the dualism of street and architecture. The dividing line between road and architecture will disappear, but the architectures become roads and the colonnaded streets are architectures. At the point of intersection between thistle and decumanus, an oval square opens up to which the task of re-designing the public space is entrusted, an approach that demonstrates greater control, the idea of defining a morphological model that places commercial units within urban spaces while maintaining the characteristics of the stoà.

The examination of these morphological paradigms allows us to define how in Palmira (fig. 6) entering the Damascus gate the colonnaded street becomes an oval colonnaded, which together with the gate and the next street, also delimited by columns, constitutes a unitary architectural intervention. Palmira developed on already consolidated patterns [De Micheli 200 I, p. 57] and functions where the rhythmic rhythm of the columns, in the alternation of full and empty spaces, makes the street architecturally homogeneous, without there being any emerging or particularly monumental elements. The colonnade becomes the control

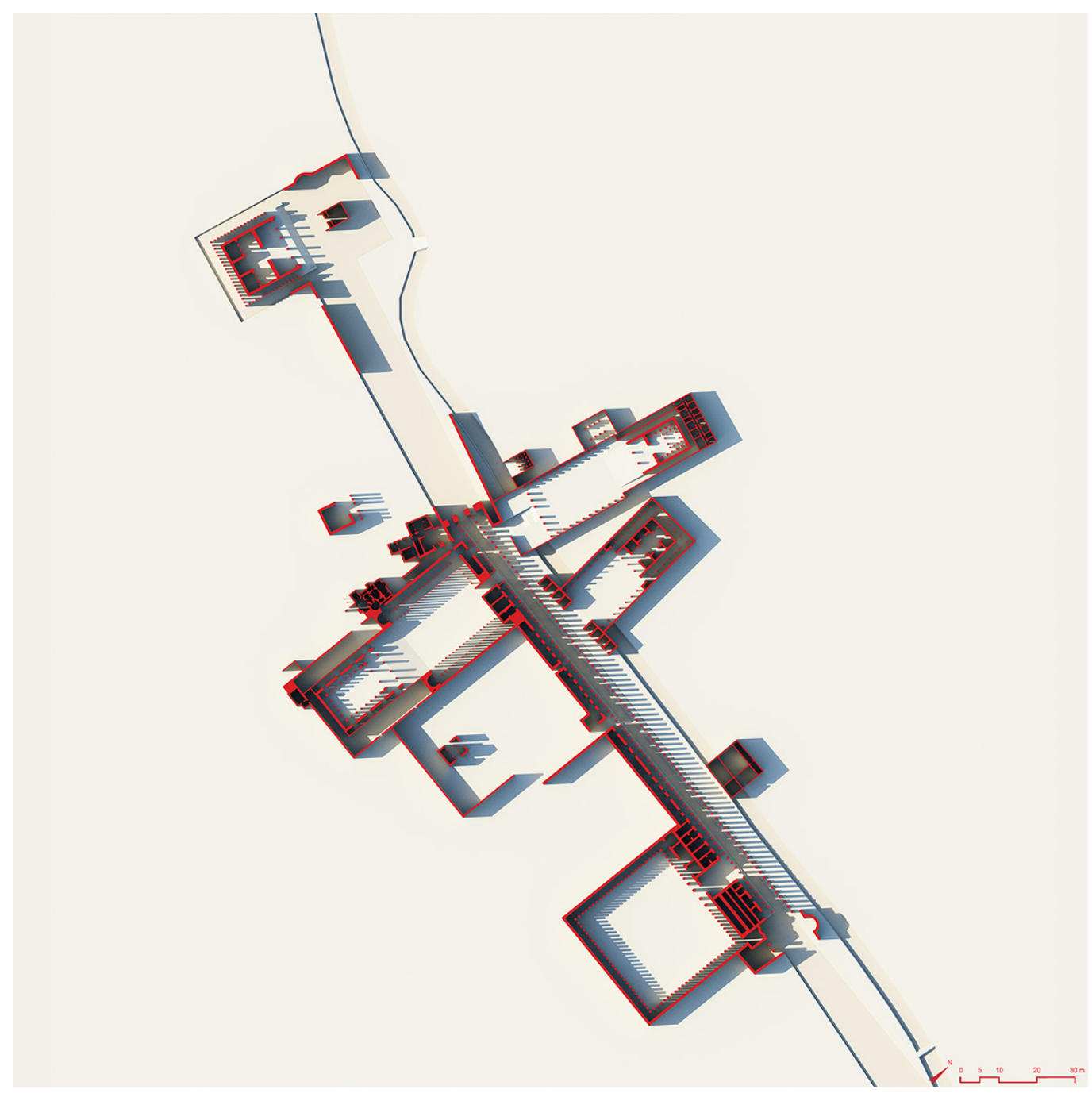


Fig. 5. For a model: Jerash (graphic elaboration by
Francesco Trimboli).
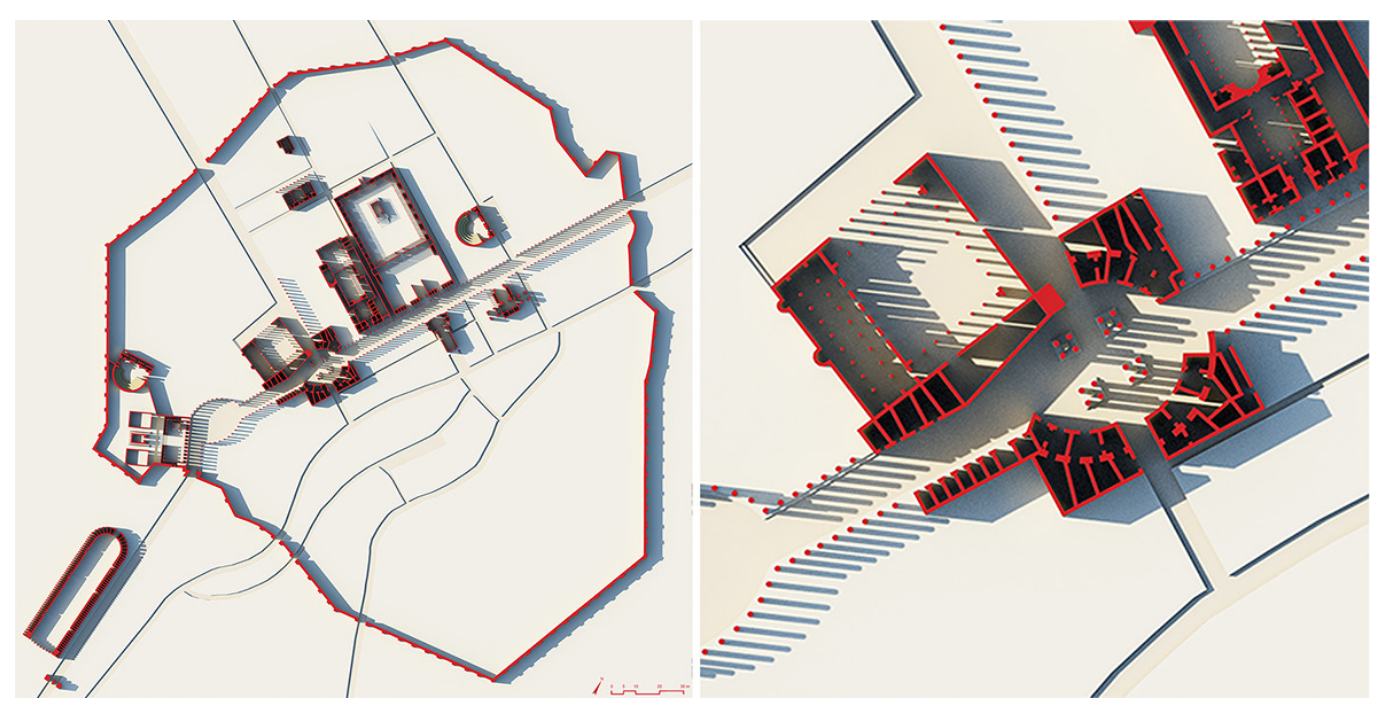

Fig. 6. For a model. Palmira (graphic elaboration by Francesco Trimboli).

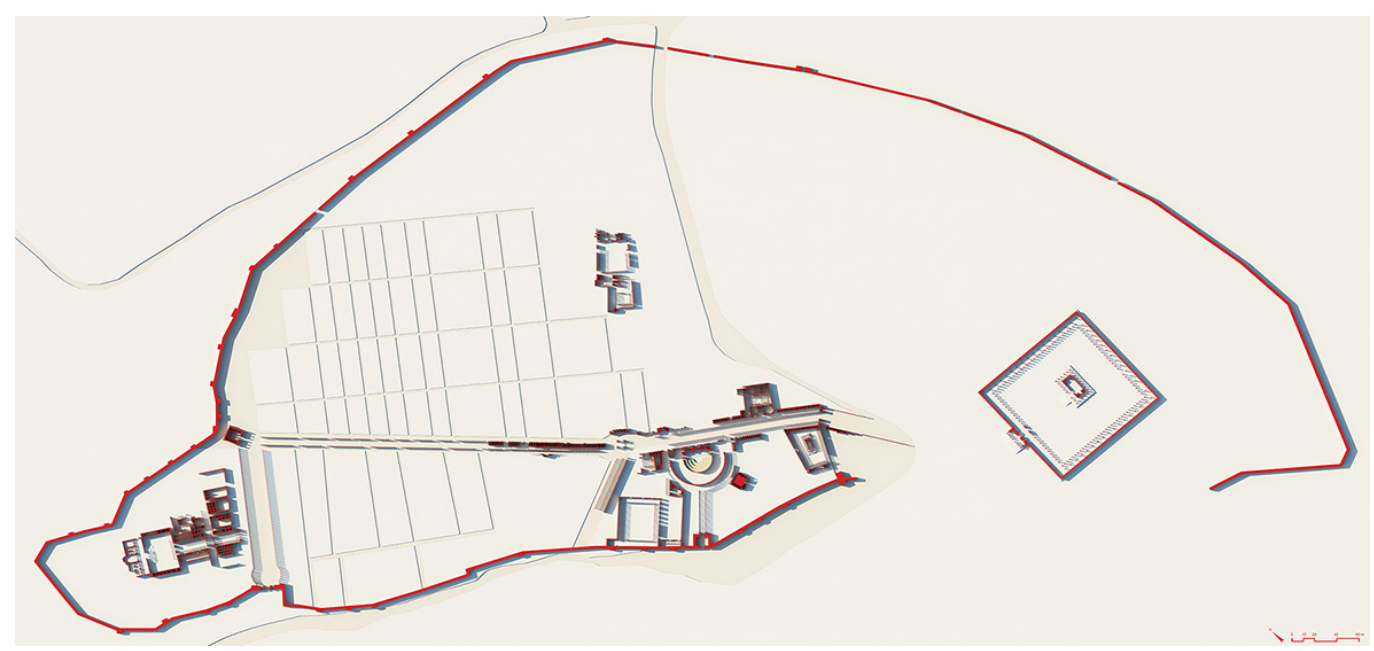

Fig. 7. For a narration. Three-dimensional models, as morphogenetic narration of the colon-

nade street in the cities of Ephesus, Petra, Jerash and Palmira (graphic Trimboli).
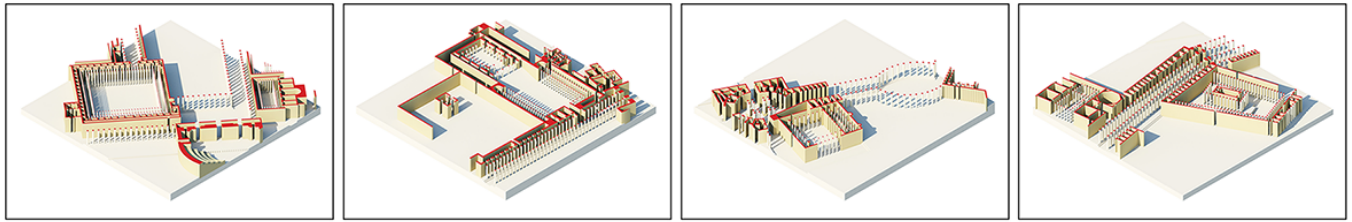
element of urban morphology, which does not arise suddenly by altering the original identity of the place, it is the desert that becomes matter. Consequently, the morphological fabric is no longer a place known from a demanding architecture, but an experiential place where a colonnaded device animates the urban scene [Branzi 2007, p. 46] (fig. 7).

A scene that can be narrated through the frames, a storyboard that traces the rhythm marked by the columns and which becomes the tangible tool with which to scan the visible traces of an architecture that becomes a memory, notes for a representation. (fig. 8).

The architectural re-proposed in writing this work can be traced back to the formal transcription of the city which today presents itself as a sort of residue of the original form.
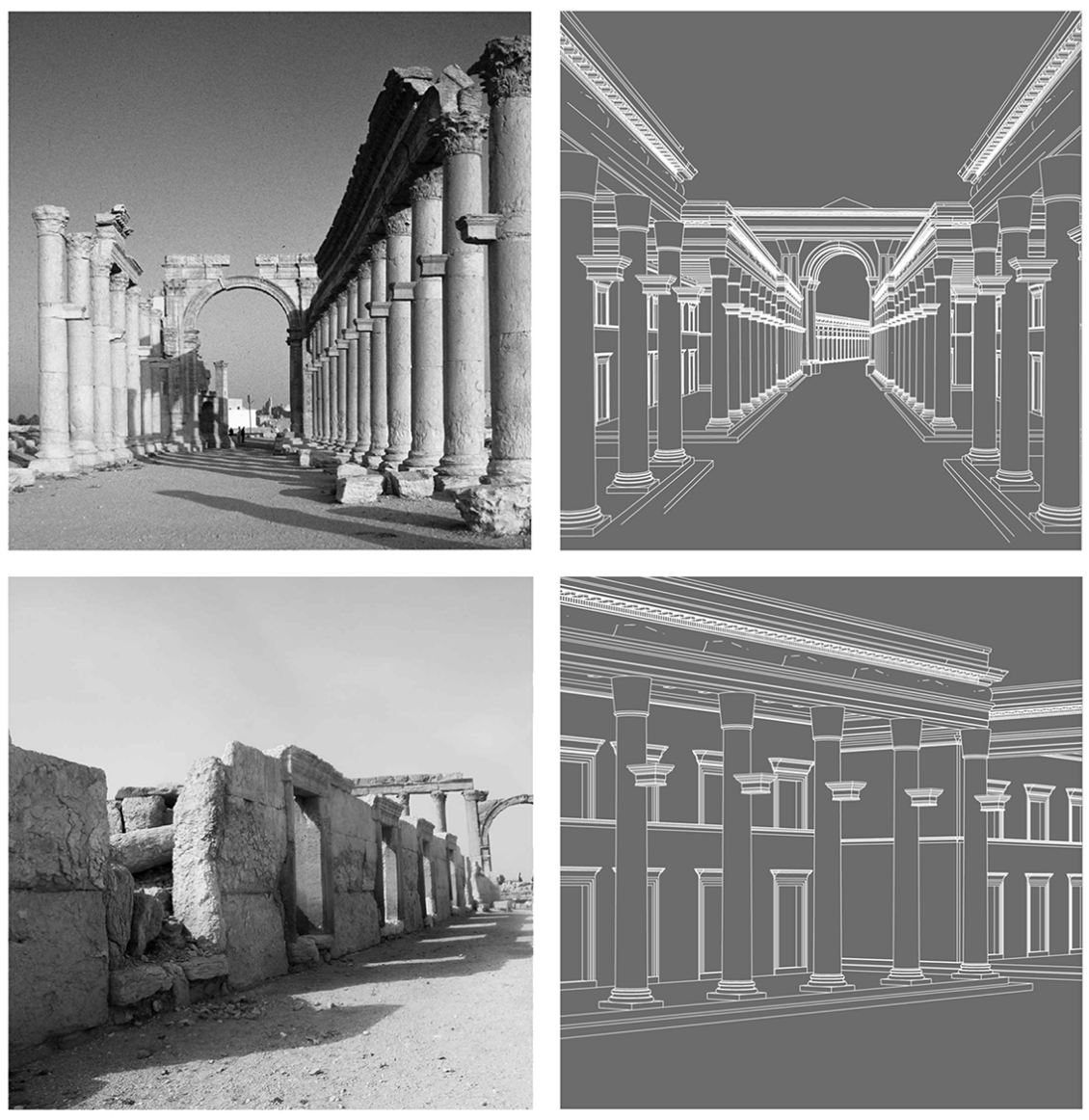

Fig. 8. Notes for a representation. From sign to model. Digital model of the triumphal arch, shops and tetrapylon. Case and tetrapylon. Case study Palmira (graphic
elaboration by Francesco Trimboli).
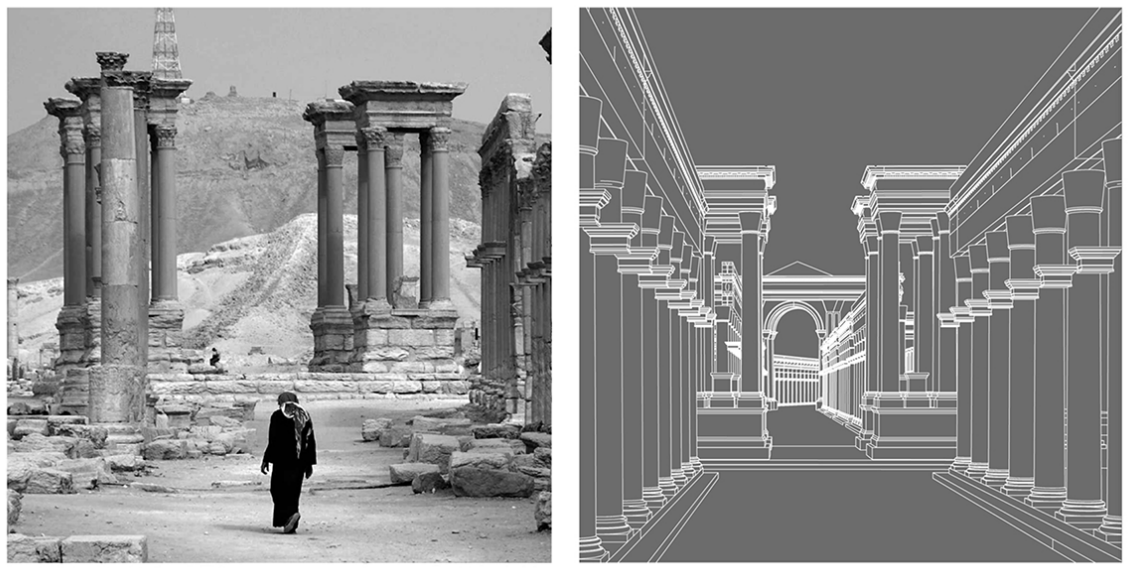
A sign as memory. The drawing as a formal tool to recognize the ability to question the issues of design. Drawing as a project. This is the aim of the work presented, to reflect on themes that are disappearing to highlight, through an iconic representation (fig. 9) the morphological synthesis of the characters that make-up these urban fabrics, whose permanence constitutes the main element of continuity with the Roman-Byzantine age [Arce 2006], a mirage of all the characteristics of the vision [Branzzi 2007].

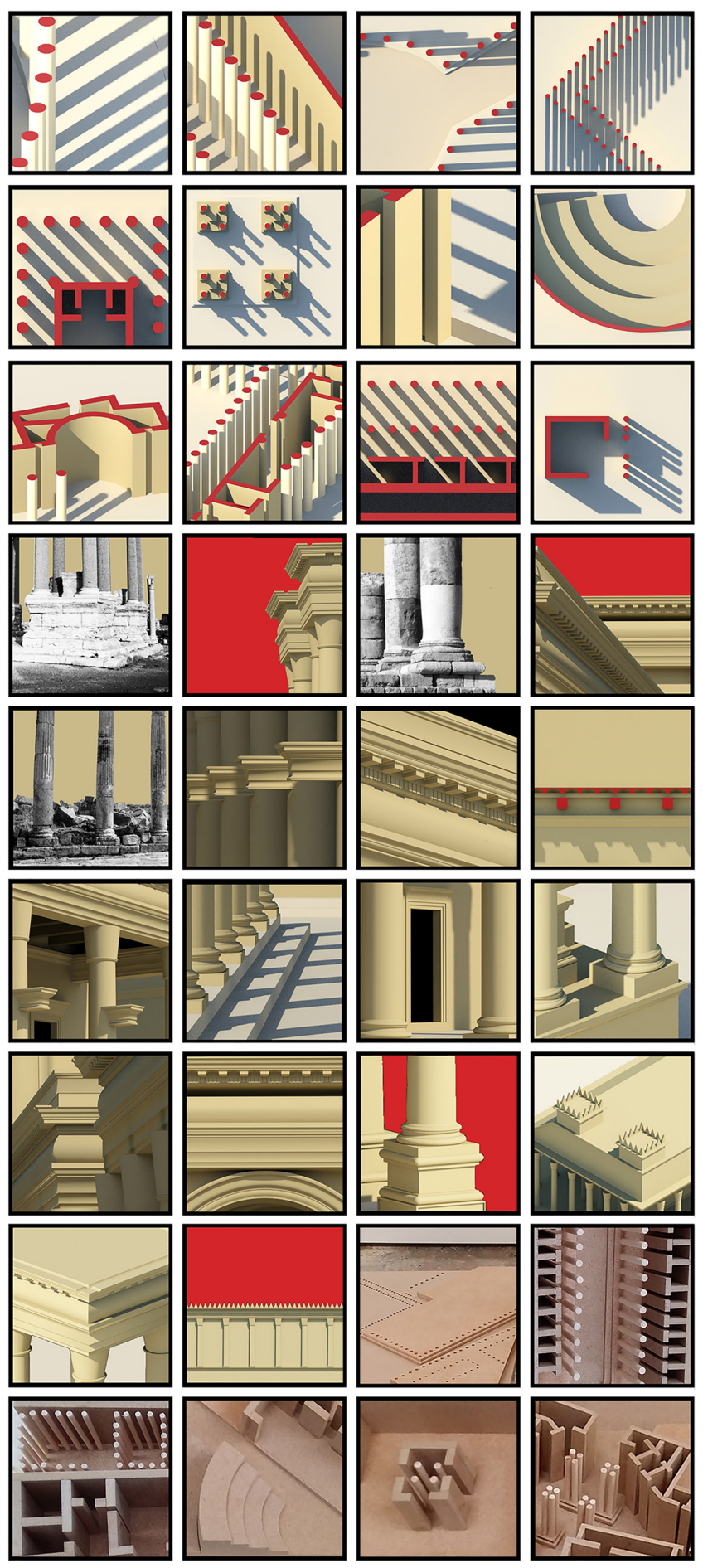




\section{Notes}

[I] The presented topic was developed in a first analysis in the author's Degree Thesis, Francesco Trimboli La strada come architettura. Le vie colonnate nelle terre di Efeso Jerash, Petra e Palmira. Degree Thesis in Architecture and Building Engineering LM-4, discussed in the 2015-2016 academic year at the Mediterranean University of Reggio Calabria, of which supervisor Prof. Arch. Gaetano Ginex.

[2] "L'analisi dell'idea formalizzata, la sua scomposizione, la sua visione da ogni punto di vista reale e irreale, il suo attraversamento e la contemporanea indagine di più punti tra loro non contigui e non visibili" (M.S. 2007), è ciò che la rende significativa. Un susseguirsi di elementi che come sineddoche si awiano a dare degli esiti formali miracolosamente "banali", ma pur sempre rappresentativi di un idea" [Ginex 201 I].

\section{References}

Arce Ignacio (2006), Umayyad Arches,Vaults and Domes: Marging and Re-Creation. Contributions to Early Islamic Construction History. In Dunkeldt Malkom et al. (eds). Proceeding of the Second Internetional Confress on Construction History. Exter: Cambrige Editions, vol. I, pp. 195-220

AA.V. (20।4). Palmira: impianto urbano, via colonnata e ninfeo B. Lecce:Youcanprint.

Bejor Giorgio (1999). Vie Colonnate. Paesaggi urbani del mondo antico. Roma: Giorgio Bretschneider Editore.

Branzi Andrea (2007). Dall'arredo alla scenografia urbana. In Brazi Andrea. Capire il design. Firenze: Giunti editore.

Cabiale Valentina (20II). La lunga durata delle vie colonnate nella regione siro-palestinese. Dai Bizantini agli Omayyad. In Archeologia Medievale, XL, 20 I 3 - Fortificazioni di terra in Italia. Motte, tumuli, tumbe, recinti. Atti del Convegno, Scarlino, I4- I6, pp. $321-330$.

Calvino Italo (1972). Le città invisibili. Torino: Einaudi.

Cerasi Maurice (2005). La città dalle molte culture: l'architettura nel Mediterraneo orientale. Limena: Libri Scheiwiller.

Ginex Gaetano (20II). Strutture Formali e Alfabeti compositivi. Impianti urbani romani nelle regioni desertiche del Mediterraneo. Progetto di un sistema interattivo per la conoscenza e la gestione del patrimonio culturale del Mediterraneo. In Giovannini Massimo, Prampolini Franco ( cura di).Spazi e Culture del Mediterraneo 3. Reggio Calabria: Centro Stampa d'Ateneo, pp. $301-320$.

Ginex Gaetano (20 I I), Progettare con gli archetipi. In AAVV. Le città del Mediterraneo. Atti del IV Forum Internazionale di Studi, Reggio Calabria giugno 201 I. Reggio Calabria: liriti Editore.

Ginex Gaetano (2017). Nefta e le città oasi di Nefta, Tamerza, Mides e Chebika. Reggio Calabria: Iriti editore, Reggio Calabria.

Neglia Giulia Annalinda (2009). Medina. Saggi sui paesaggi urbani delle città del Mediterraneo sud-orientale. Bari: Polibarpress AGF.

Rostovtzeff Michail (201 I). Città carovaniere. Roma: Pgreco.

Brenk Beat (2008), The end of the Roman temple I73- 185 and the end of the Chatedral church of Jerash. In Farioli Campanati R. et al. (a cura di), Ideologia e cultura artistica tra Adriatico e Mediterraneo orientale (IV-X secol). II ruolo dell'autorità ecclesiastica alla luce di nuovi scavi e ricerche. Atti del Convegno Internazionale. Bologna - Ravenna, 26-29 novembre 2007. Bologna: Ante Quem.

\section{Author}

Francesco Trimboli, Università degli Studi Mediterranea di Reggio Calabria, francesco.trimboli@unirc.it

To cite this chapter. Trimboli Francesco (2020). La strada come architettura. Le vie colonnate nelle terre di Efeso, Jerash, Petra e Palmira. Appunti per una rappresentazione/The street as architecture. The colonnaded streets in the lands of Ephesus, Jerash, Petra and Palmyra. Notes for a representation. In Arena A., Arena M., Brandolino R.G., Colistra D., Ginex G., Mediati D., Nucifora S., Raffa P. (a cura di). Connettere. Un disegno per annodare e tessere. Atti del $42^{\circ}$ Convegno Internazionale dei Docenti delle Discipline della Rappresentazione/Connecting. Drawing for weaving relationships. Proceedings of the 42th International Conference of Representation Disciplines Teachers. Milano: FrancoAngeli, pp. 22803-2820. 